\title{
Engineering Students' Approaches to Learning and Views on Collaboration: How do both Evolve in a PBL Environment and What are their Contributing and Constraining Factors?
}

\author{
Xiangyun Du ${ }^{1 *}$, Usama Ebead ${ }^{2}$, Saed Sabah ${ }^{1}$, Jianping Ma ${ }^{3}$, Khalid Kamal Naji ${ }^{2}$ \\ ${ }^{1}$ College of Education, Qatar University, QATAR \\ ${ }^{2}$ College of Engineering, Qatar University, QATAR \\ ${ }^{3}$ Graduate School, Lanzhou University of Technology, CHINA
}

Received 24 February 2019 • Revised 4 April 2019 • Accepted 6 April 2019

\begin{abstract}
Background: This study investigated the development of engineering students' approaches to learning and views on collaboration in a PBL environment.

Material and methods: An explanatory mixed research approach was employed with participants from four PBL-implementing engineering courses in Qatar and China. 197students responded to two surveys, and 168 students participated in group interviews.

Results: While the study reveals increased adoption of deep approaches to learning on team projects, little influence on surface approaches to learning was found. The study also provides evidence supporting the positive relationship between students' adoption of deep learning approaches and their acknowledgement of values of collaboration in teamwork.

Conclusions: This study suggests that while PBL characteristics may support deep learning, certain factors may underpin surface learning, including a feeling of insecurity during first experiences with it, lack of skills, and assessment methods that favor surface learning. Further efforts on engaging students with PBL may benefit both deep learning and team effectiveness.
\end{abstract}

Keywords: engineering education, PBL, deep/surface approach to learning, student views on collaboration, China and Qatar

\section{INTRODUCTION}

Problem and/or Project (PBL) based learning - referring to a problem, a project or a combination of both-is increasingly being implemented in engineering education around the world, driven by the need for new engineering competences (Kolmos \& De Graaff, 2014), a lack of graduates' readiness for the workplace (Strobel \& Van Barneveld, 2009), and new demands spurred by changing accreditation procedures (Beddoes, Jesiek, \& Borrego, 2010). PBL addresses all requested student learning outcomes in accreditation (Felder \& Brent, 2003) and is a recognized pedagogical choice that encourages students to work in teams and seek solutions to complex reallife problems (Helle, Tynjälä, \& Olkinuora, 2006; Hmeo-Silver, 2012). A rich body of literature has documented PBL's effectiveness in fields such as the health profession, and other literature has concluded that PBL has positive effects on professional skill development in engineering education (Prince \& Felder, 2006). However, the majority of the literature has focused on the description of PBL courses or programs in conjunction with student experiences and perceptions (Beddoes, Jesiek, \& Borrego, 2010). Evidence on PBL's effect in engineering education remains limited, and therefore further research is desired (Beddoes, Jesiek, \& Borrego, 2010), particularly as regards seeking

(C) 2019 by the authors; licensee Modestum Ltd., UK. This article is an open access article distributed under the terms and conditions of the Creative Commons Attribution License (http://creativecommons.org/licenses/by/4.0/). $\square$ xiangyun@qu.edu.qa (*Correspondence) $\nabla$ uebead@qu.edu.qa $\square$ ssabah@qu.edu.qa $\square$ majp326@lut.cn 


\section{Contribution of this paper to the literature}

- The study contributes to the literature on engineering education with evidence of improved deep learning adaptions, higher values of collaboration and sustaining use of surface learning after implementing PBL.

- Significant supporting evidence of a co-relationship between students adopting a deep learning approach and rating collaborative teamwork more highly, suggest that engaging students in PBL may benefit both deep learning and team effectiveness.

- This study also contributes to the PBL literature by identifying the benefits and challenges and analyzing contributing and constraining factors of implementing PBL in engineering education at the course level.

new insight into a variety of PBL practices rather than assuming that all PBL stems from the same practices (Helle, Tynjälä, \& Olkinuora, 2006).

A substantial body of literature has long been dedicated to assessing how students experience their studies and whether they develop deep learning in higher education (Asikainen \& Gijbels, 2017; Prosser \& Sze, 2014). Meanwhile, in engineering education, tremendous efforts have been made to enhance active learning and promote deep learning (Prince \& Felder, 2006). A PBL environment can be used to increase students' deep approaches to learning due to its characteristics of active learning and self-directed learning (Dolmans, Loyens, Marcq, \& Gijbels, 2016); nevertheless, previous studies have reported inconsistent and ambiguous results and little is known about whether engineering students develop deep learning in a PBL environment.

Being a prevalent method used in professional engineering practice, teamwork is being increasingly emphasized as a curriculum component and expected outcome of many engineering programs (Borrego, McNair, \& Beddoes, 2013). Although it is commonly believed that team projects are valuable in preparing engineering students for their profession (Borrego, Karlin, McNair, \& Beddoes, 2013), little is known about how students understand collaboration and view their own collaborative efforts in the process of a team project.

Therefore, this study aims to investigate engineering students' approaches to learning and views on collaboration, in addition to placing particular focus on PBL's potential for developing deep learning and positive views on collaboration in the initial stage of changing to a PBL environment at the course level. With these purposes, the current study took place in a context of engineering courses under the efforts of changing from lectures to PBL methodology, a change initiated by course instructors. An explanatory mixed research approach is employed to generate both quantitative and qualitative data, sampling 197 students from four engineering courses in Qatar and China. Although higher educational institutions in both countries have been called to make pedagogical changes to provide students with profession-related competences over the last decade, a lecture-based approach remains the prevailing teaching method (Du, Su, \& Liu, 2013; Du, et al., 2016, 2019; He, et al., 2018; Sabah \& Du, 2018; Zhao, Zhang, \& Du, 2017).

\section{LITERATURE REVIEW}

\section{Approaches to Learning in Higher Education}

Students' approaches to learning refer to their intentions, motives, and strategies as they go about learning (Marton \& Saljö, 1976a, b). Marton and Saljo (1976a, b) found two levels of student information processing that may influence learning outcomes; these are labelled as deep and surface. The intent of students in deep approaches to learning was to comprehend the meaning of the material, which leads to coherent and relational understanding with long-term retention and application (Biggs \& Tang, 2011; Prosser \& Trigwell, 1999). A surface approach is one in which students focus on reproducing the contents and processes in the short term-often for examination purposes - and it is therefore characterized as reproductive and unreflective (rote learning) (Biggs \& Tang, 2011; Prosser \& Trigwell, 1999). In the original research, the examination of approaches to learning was mainly focused on learners' ways of processing, but further studies have emphasized the approaches to learning as a way to organize one's study (Entwistle, 2009); more broadly, the current concept of approaches to learning includes perspectives such as motivation, intention, strategies, and achievement (Asikainen \& Gijbels, 2017; Dolmans, Loyens, Marcq, \& Gijbels, 2016; Kember, Biggs, \& Leugn, 2004).

Approaches to learning are not stable, but change as a result of the interaction between the contextual aspects, including the learning environment, instructors, peer students, and learners' individual characteristics (Biggs \& Tang, 2011; Entwistle, 2009). A student's choice of approach is to some extent shaped by his or her past experience, but is more largely influenced by the conditions and environment of a course (Entwistle, 2009). Educational contexts, conditions, expectations (e.g., nature of tests), and forms of interactions have a considerable effect on student approaches to learning. Therefore, approaches to learning, instead of diagnosing students' traits, reflect both individual characteristics (learner engagement) and the teaching contexts (the enabling conditions), and 
describe the nature of "the relationship between student, context, and the task" (Kember, Biggs, \& Leugn, 2004, p263).

Although several studies have investigated whether students' approaches to learning change in higher education, the results remain ambiguous and there is a lack of agreement (Dinsmore \& Alexander, 2012). In their recent review on the development of students' deep and surface approaches to learning in higher education, Asikainen and Gijbels (2017) identified 43 relevant studies published since the 1970s. Concerning the deep approach, eighteen of these studies reported a positive development, eight found a decrease, and the rest reported no significant changes. Meanwhile, concerning the surface approach, eleven of these studies reported a decrease, nine found an increase, twenty reported no change, and the rest did not discuss the surface approach at all. Pertinent to our current study, of the 43 studies analyzed above, only one (De Clercq, Galand, \& Frenay, 2013) used first year engineering students as participants, but did so without reporting any data on changes of the approaches to learning. Overall, our literature review was inconclusive as to the results of previous studies regarding whether students have developed deep approaches to learning in higher education. Many authors suggested that further studies on approaches to learning should take into account the teaching and learning context and would be better conducted at the course level or in even more micro settings.

Approaches to learning are context specific (Bigg \& Tang, 2011; Entwistle, 2009). In their review, Baeten, Kyndt, Struyven, and Dochy (2010) suggested that student-centered learning environments have positive effects on stimulating deep approaches to learning on all education levels. Following this, it is also assumed that problemand/or project-based learning (PBL) that demands active and self-directed learning should encourage deep learning (Dolmans, Loyens, Marcq, \& Gijbels, 2016). In their recent review of deep and surface learning in PBL, Dolmans, Loyens, Marcq, and Gijbels (2016) identified 21 relevant studies and found that PBL enhances deep learning and has little effect on surface learning; in particular, the effect of PBL on deep learning is more significant at a curriculum level than at a single course level. Nevertheless, the review suggests that PBL's effect on deep learning requires more evidence from strong theoretical frameworks and more validity.

\section{Student Views on Collaboration in Higher Education}

Teamwork has frequently been used to organize student projects in engineering education to meet their professional learning outcomes (Borrego, Karlin, McNair, \& Beddoes, 2013). A project team can refer to a group of individuals working on interdependent tasks within a defined time period using shared responsibilities and goals to reach a certain result/product (Chiocchio \& Essiembre, 2009, 390-91). Surrounding the concept of collaboration are such terms as collaborative learning, cooperative learning, teamwork, and groupwork. In this study, we use them interchangeably without distinguishing any differences. Several educational and learning theories can be related to project teamwork. Emphasizing students' views on collaboration in a team project, the current study is embedded in the constructivist approach to learning, which places learners' problem solving, the generation of meanings through interaction, and the co-constructing of new knowledge at the core of PBL (Schmidt, Van der Molen, Te Winkel, \& Wijnen, 2009). Specifically, we use the conceptual framework of knowledge building because it focuses on collective cognitive responsibility and engaging students in a community to create new knowledge (Scardamalia \& Bereiter, 2006), which is aligned with the anticipated goals of engineering project teamwork. Scardamalia (2002) characterized 12 principles that guide the social-cognitive dynamics of collaboration from a knowledge-building perspective. These include improvable ideas, community knowledge, synthesizing ideas into new knowledge, diversity of ideas, democratizing knowledge, goal setting and planning, idea exchange for knowledge-building discourse, simultaneous assessment, knowledge exchange among groups, constructive use of information, authentic problems, and relevant knowledge building. These principles form a complex interactive system supporting the design of classroom work and examining knowledge building (Chan \& Chan, 2011). A knowledge-building approach is reported to be a useful tool for documenting collaborative inquiry and knowledgecreating processes in a project-based team context (Chan \& Chan, 2011).

\section{Approaches to Learning, Views on Collaboration and PBL in Engineering Education}

Previous studies have reported a positive relationship between deep approaches to learning with high levels of learning efficacy (Phan, 2011), approaches that build confidence in problem solving and goal mastery (De Clercq, Galand, \& Frenay, 2012), approaches that involve self-regulation and cognitive strategies (Heikkilä \& Lonka, 2006; Loyens, Gijbels, Coertjens, \& Cote, 2013), and student outcomes and success (Trigwell \& Prosser, 1991). Despite the amount of attention paid by researchers to student approaches to learning and collaborative learning, respectively, few studies have examined approaches to collaboration (Zhao \& Zheng, 2014) and the relationship between these two important aspects of student learning (Chan \& Chan, 2011) in engineering education in general and in a PBL environment specifically, where deep learning and teamwork are both emphasized. 
Among the studies reviewed by Dolmans, Loyens, Marcq, and Gijbels (2016), only one focused on engineering education in PBL. In this study, Schultz and Christensen (2004) reported increased deep learning and reduced surface learning in an interaction design course by using seven-step problem-based learning in Denmark. However, this study was based on a small sample (30 students) with only one association measurement (post) and did not report reliability and validity results. In addition, based on two qualitative studies in the UK and South Africa, Case and Marshall (2004) identified a continuum of change between surface to deep approaches to learning, depending on the engineering students' perceptions of the course contexts when problem-solving skills were prioritized.

Over time, many studies have been published on engineering team projects; however, most of them have focused on describing a course practice, reporting student perceptions, or measuring team performance. In their systematic review of 72 studies on engineering student project teams, Borrego, Karlin, McNair, and Beddoes (2013) found most published studies failed to engage with the literature or relevant theories, and only a few of them used management or psychology theories related to team development and learning outcomes. Although over ten studies were identified as being related to a PBL environment, they mostly took into account first-year students or capstone projects. While it is assumed that team projects are valuable for preparing engineering students for their profession (Borrego, Karlin, McNair, \& Beddoes, 2013), little is known about how students understand collaboration and view their own collaborative efforts in the process of a team project.

In the Middle Eastern context, PBL remains a new phenomenon. While a few studies presented engineering students' positive experiences with PBL when the method was implemented as an institutional approach in Australian College of Kuwait (Al Mughrabi \& Jaeger, 2017; Jaeger \& Adair, 2014), further educational and research attention is needed on implementing PBL in the Middle Eastern context. In Qatar, in higher educational settings, PBL was implemented in the newly established medical school as a way to provide professional competences (Du, et al., 2016, 2019); nevertheless, more results were expected regarding students' experiences and outcomes. Recent studies also identified challenges confronted in initial implementation of PBL in Qatar, including students' lack of understanding and skills required for PBL (Du, et al., 2016), teachers' lack of understanding and skills for innovative pedagogical methods, and restriction from overall curriculum requests (Du, et al., 2019; Sabah \& Du, 2018).

In mainland China, PBL is recently receiving attention by educators and researchers. A number of studies have reported evidence of students' development in critical thinking (Du, Emmersen, Toft, \& Sun, 2013) and problemsolving skills (2017) in medical programs, and improvement of reflection and collaboration in business programs (Zhao, Zhang, \& Du, 2017; Zhao \& Zheng, 2014), while another study reported students' development of critical thinking, collaboration, and sustainability thinking in engineering and science programs. While PBL is being increasingly regarded as a useful methodology for engineering education in China, more research evidence is needed to document its impact on student learning.

Therefore, the current study aims to examine whether or not engineering students develop deep approaches to learning and views on collaboration in the context of implementing PBL at the course level and the relationship between engineering students' approaches to learning and views on collaboration. The following research questions will be explored in this paper:

(1) What are engineering students' approaches to learning and views on collaboration?

(2) Do student approaches to learning and views on collaboration develop throughout the PBL process?

(3) Are the students' approaches to learning correlated with their views on collaboration?

(4) What benefits and challenges are perceived by the engineering students in their initial PBL experiences?

\section{METHODS}

\section{Contexts}

The study was carried out during the spring and fall semesters of 2018 in four third-year engineering courses (three in College of Engineering in Qatar University in Qatar and one in Lanzhou University of Technology, China) that were at an initial stage of changing from a lecture-based method to a problem-and project-based learning method (PBL). Both institutions encouraged instructors to implement diverse student-centered methods in order to provide profession-related skills for the prospective graduates. Course instructors in this study all volunteered to participate in PBL pedagogical development programs, with the first author of the study as a facilitator. Inspired by this experience with the PBL method, these instructors made efforts to change their courses to PBL using a bottom-up approach. The four courses in this study are the first in-class PBL encounters for both instructors and students.

Due to the fact that these instructors decided on the initiative of implementing PBL based on their own motivation and interests instead of an institutional request, they made efforts in the design of their courses with the support of the first author of the study, who works internationally to support pedagogical development for 
EURASIA J Math Sci and Tech Ed

Table 1. Overview of the Participants

\begin{tabular}{llccccc}
\hline Class number & Name of course & $\begin{array}{c}\text { Number of class } \\
\text { participants }\end{array}$ & $\begin{array}{c}\text { Number of } \\
\text { project } \\
\text { teams }\end{array}$ & $\begin{array}{c}\text { Number of } \\
\text { survey } \\
\text { participants }\end{array}$ & $\begin{array}{c}\text { Number of focus } \\
\text { group } \\
\text { participants }\end{array}$ & Gender \\
\hline 1 (Qatar) & $\begin{array}{l}\text { Design of RC } \\
\text { Structures }\end{array}$ & 32 & 6 & $24(80 \%)$ & $30(93 \%)$ & All male \\
\hline 2 (Qatar) & $\begin{array}{l}\text { Design of RC } \\
\text { Members }\end{array}$ & 24 & 4 & $20(83 \%)$ & $23(96 \%)$ & All male \\
\hline 3 (Qatar) & $\begin{array}{l}\text { Construction } \\
\text { Engineering }\end{array}$ & 37 & 7 & $33(89 \%)$ & $35(95 \%)$ & All male \\
\hline 4 (China) & $\begin{array}{l}\text { Pharmaceutical } \\
\text { Chemistry }\end{array}$ & 122 & 20 & $120(98 \%)$ & $100(82 \%)$ & 65 male, \\
\hline Total: 4 & & 215 & 37 & $197(92 \%)$ & $188(87 \%)$ & $\begin{array}{c}153 \text { male } \\
35 \text { female }\end{array}$ \\
\hline
\end{tabular}

PBL. Following PBL principles in engineering education suggested by Kolmos and De Graaff (2014), the PBL teaching designs in the four courses included a process of problem initiation and analysis, project organization as the core of the course, lectures playing a supportive role, and teamwork project reports as final PBL outcomes.

Considering that this was a first experience, the course instructors all designed the overall theme of the project with a designated theme based on a real-life problem, after which each student team chose a particular aspect to focus on their projects. During the majority of the contact teaching hours, students worked in groups on the projects and the instructors served as facilitators, walking around the groups while providing advice and discussion for the students. Some lectures (less than $30 \%$ of total contact hours) were provided to support project work in addition to a list of suggested materials on the course platform via online learning sources.

Guided by the principles of constructive alignment (Biggs \& Tang, 2011), alternative assessment methods were designed, changing from $100 \%$ individual written exams to a method consisting of $60 \%$ group project assessment throughout the semester (divided into three stages of project progression) and $40 \%$ divided into different team assignments or individual assessments (the four course instructors handled this $40 \%$ differently according to the course objectives). Rubrics were provided to students to guide their projects from the start.

\section{Participants}

Table 1 presents participants' information. All engineering students from the four classes $(n=215)$ were invited to join the study. A total of $197(92 \%)$ students responded the questionnaires, distributed across Qatar $(n=77)$ and China $(n=120)$. To collect the qualitative data, 37 group interviews were conducted, amounting to the voluntary participation of $188(87 \%)$ students in total. Participants in Qatar were only male due to the campus being separated by gender and all three classes where PBL was implemented coming from the male side.

\section{Data Generation and Analysis}

An explanatory mixed-method research approach (Creswell \& Clark, 2017) was designed for data generation, which included two phases: a quantitative study using two questionnaire surveys on approaches to learning and views on collaboration, and a qualitative study using focus group interviews to triangulate the quantitative data and further explore reasons and factors through emerging patterns (Kvale \& Brinkmann, 2009).

Two questionnaire surveys were employed to collect the quantitative data. According to the review by Dinsmore and Alexander (2012), different frameworks may be one reason for the ambiguity of the results of student approaches to learning; therefore, this study employed a commonly used instrument called the Biggs Study Process Questionnaire, which is the revised two-factor version of the Learning Process Questionnaire (R-LPQ-2F) (Kember, Biggs, \& Leugn, 2004). This instrument has been developed, revised, and validated over decades of research for the purpose of investigating approaches to learning, specifically at the course level. Consisting of 22 items, the questionnaire has two factors, namely deep and surface approaches to learning. Each factor can be further classified into four dimensions; the deep approach includes intrinsic interest, commitment to work, relating ideas, and understanding, while the surface approach consists of fear of failure, aim for qualification, minimizing scope of study, and memorization.

The questionnaire on views on collaboration, composed of 12 items, was developed by Chan and Chan (2011), and is based on Scardamalia and Bereiter's (2006) knowledge-building principles. Although the original study was conducted in the context of an online learning environment, it also serves in face-to-face collaboration (Chan \& Chan, 2011). Students were asked to use a 5-point Likert scale to rate the items based upon reflecting on their experience of collaboration. 
Both surveys were measured twice, being given before and after the PBL course with instances approximately 4 months apart. Questionnaires were administrated in paper-pencil form; In Qatar, English was used because English is the official language of the study program, while bilingual questionnaires (Chinese and English) were used in China. The questionnaires were translated from English into Chinese using back-translation in order to examine the translation's validity and linguistic parallelism (Cohen, Manion, \& Morrison, 2013). Both questionnaires were validated with minor revision by experts and via pilot studies in both countries.

The quantitative data analysis was based on: the analysis of (1) an exploratory factor analysis of each of the two instruments and a reliability analysis of each factor; (2) the descriptive statistics to identify the means of both instruments, including deep-approach factors, surface-approach factors, and views on collaboration; and (3) t-tests to analyze the differences in participants' approaches to learning and views on collaboration before and after PBL implementation in each class.

The quantitative data analysis results drove the need for focus group interviews (Kvale \& Brinkmann, 2009). The interview findings were used to triangulate the survey results and further explore participants' elaboration of reasons, perceived opportunities, and encountered challenges. Through open questions, participants were invited to talk more freely and deeply about their experiences of team-based project work during the course. Examples include: "Could you please describe your project process through the course, such as goals, schedules, and modes of working together?", "Can you explain why it was important to take that strategy?", and "Can you provide an example of how you coped with such a challenge?". Follow-up clarifying questions were also asked. Each group interview lasted between 30-60 minutes and was conducted in English with participants in Qatar and Chinese with participants in China. The interviews were audio-recorded, transcribed, and translated into English.

The interview analysis process had several phases. First, an inductive content analysis technique was conducted to reveal individual and group responses by defining patterns of communication and inferring meanings via linguistic features in the given contexts (Cohen, Manion, \& Morrison, 2013). Through thematic analysis focusing on meaning condensation, outlines of the meanings expressed by the interviewees were coded and categorized into shorter formulations (Kvale \& Brinkmann, 2009). Then, the initial findings were compared to the survey results for triangulation, after which the contextual factors relating to the reasons for students' change regarding deep learning, surface learning, and views on collaboration on the pre and post course surveys were identified. Following this, we identified opportunities and challenges perceived by participants and again compared these patterns to the quantitative results to reach an alignment. In the process of analysis, the interpretation did not only rely on the described events as facts, but more importantly included an understanding of the participants' social discourse that provided background to their words (Cohen, Manion, \& Morrison, 2013). Finally, we discussed the results and patterns until agreement was reached on interpretation and the patterns.

\section{RESULTS}

\section{Quantitative Results}

\section{Approach to learning}

The exploratory factor analysis of the 22 items was loaded onto the two expected factors - deep approach (DA) and surface approach (SA). However, two items (S3 and S4) were not loaded under the expected factors of SA, so they were excluded. The two factors explained $16.88 \%+14.31 \%$, amounting to $31.19 \%$ of the total variances. Table 2 reports the details.

As Table 2 shows, the results indicate that students from all four classes reported a significant improvement in the deep approach to learning after having completed a PBL course (Class 1: $\mathrm{t}=-4.87, \mathrm{p}=.000$, Class 2: $\mathrm{t}=-4.36$, $\mathrm{p}$ $=.000$, Class $3: \mathrm{t}=-4.08, \mathrm{df}=31, \mathrm{p}=.000$, Class $4: \mathrm{t}=-5.99, \mathrm{df}=118, \mathrm{p}=.000)$. The results suggest an unchanged selfreporting of the surface approach by students from three classes (Class 1, 2 and 4) (Class 1: $\mathrm{t}=-0.138, \mathrm{p}=.89$, Class 2: $\mathrm{t}=0.11, \mathrm{p}=.91$, Class 4: $\mathrm{t}=-1.93, \mathrm{p}=.056)$, and an increase in Class 3 (Class $3: \mathrm{t}=-2.85, \mathrm{df}=31, \mathrm{p}=.008$ ). 
EURASIA J Math Sci and Tech Ed

Table 2. Approaches to Learning Results

\begin{tabular}{|c|c|c|c|c|c|c|c|c|c|c|}
\hline & \multirow[t]{2}{*}{$\begin{array}{c}\text { Cronbach } \\
\alpha\end{array}$} & \multirow[t]{2}{*}{$\begin{array}{l}\text { Factor } \\
\text { Loading }\end{array}$} & \multicolumn{2}{|c|}{$\begin{array}{l}\text { Class 1: Qatar } \\
\qquad(\mathbf{n}=\mathbf{2 4})\end{array}$} & \multicolumn{2}{|c|}{$\begin{array}{l}\text { Class 2: Qatar } \\
\qquad \mathbf{n}=\mathbf{2 1}\end{array}$} & \multicolumn{2}{|c|}{$\begin{array}{l}\text { Class 3: Qatar } \\
\qquad \mathbf{n}=\mathbf{3 3}\end{array}$} & \multicolumn{2}{|c|}{$\begin{array}{l}\text { Class 4: China } \\
n=120\end{array}$} \\
\hline & & & Pre & post & pre & post & pre & post & pre & Post \\
\hline Deep Approach (Items = 11) & .84 & & & & & & & & & \\
\hline Intrinsic Interest (Items = 3) & .69 & & & & & & & & & \\
\hline $\begin{array}{l}\text { D1 I find that at times studying makes me feel really happy and } \\
\text { satisfied. }\end{array}$ & & .63 & $\begin{array}{c}2.79 \\
(1.14)\end{array}$ & $\begin{array}{c}3.33 \\
(0.97)\end{array}$ & $\begin{array}{c}3.19 \\
(1.08)\end{array}$ & $\begin{array}{c}3.81 \\
(1.21)\end{array}$ & $\begin{array}{c}2.64 \\
(1.14)\end{array}$ & $\begin{array}{c}3.09 \\
(1.22)\end{array}$ & $\begin{array}{c}2.87 \\
(0.86)\end{array}$ & $\begin{array}{c}3.41 \\
(0.85)\end{array}$ \\
\hline $\begin{array}{l}\text { D2 I feel that nearly any topic can be highly interesting once I get } \\
\text { into it. }\end{array}$ & & .47 & $\begin{array}{c}2.62 \\
(1.13)\end{array}$ & $\begin{array}{c}3.3 \\
(0.91)\end{array}$ & $\begin{array}{c}3.29 \\
(1.23)\end{array}$ & $\begin{array}{c}3.95 \\
(1.02)\end{array}$ & $\begin{array}{c}3.24 \\
(1.00)\end{array}$ & $\begin{array}{c}3.69 \\
(0.97) \\
\end{array}$ & $\begin{array}{c}3.32 \\
(1.02)\end{array}$ & $\begin{array}{c}3.39 \\
(0.92) \\
\end{array}$ \\
\hline D3 I work hard at my studies because I find the material interesting. & & .66 & $\begin{array}{l}3.17 \\
(1.2)\end{array}$ & $\begin{array}{c}3.33 \\
(1.13)\end{array}$ & $\begin{array}{l}2.95 \\
(1.24)\end{array}$ & $\begin{array}{c}3.62 \\
(1.28)\end{array}$ & $\begin{array}{c}2.88 \\
(1.24)\end{array}$ & $\begin{array}{c}3.03 \\
(1.26) \\
\end{array}$ & $\begin{array}{c}2.62 \\
(0.87)\end{array}$ & $\begin{array}{c}2.90 \\
(0.82) \\
\end{array}$ \\
\hline Commitment to Work (Items $=4$ ) & .60 & & & & & & & & & \\
\hline $\begin{array}{l}\text { D4 I spend a lot of my free time finding out more about interesting } \\
\text { topics which have been discussed in different classes. }\end{array}$ & & .52 & $\begin{array}{c}2.54 \\
(1.03)\end{array}$ & $\begin{array}{c}2.58 \\
(1.02)\end{array}$ & $\begin{array}{c}1.90 \\
(1.09)\end{array}$ & $\begin{array}{c}2.47 \\
(1.17)\end{array}$ & $\begin{array}{c}2.03 \\
(1.07) \\
\end{array}$ & $\begin{array}{c}2.22 \\
(1.07)\end{array}$ & $\begin{array}{c}2.47 \\
(0.82) \\
\end{array}$ & $\begin{array}{r}2.75 \\
(0.88) \\
\end{array}$ \\
\hline $\begin{array}{l}\text { D5 I come to most classes with questions in mind that I want } \\
\text { answering. }\end{array}$ & & .56 & $\begin{array}{c}2.46 \\
(1.14)\end{array}$ & $\begin{array}{l}3.29 \\
(.86)\end{array}$ & $\begin{array}{l}2.24 \\
(.93) \\
\end{array}$ & $\begin{array}{c}2.95 \\
(1.12)\end{array}$ & $\begin{array}{l}2.15 \\
(1.00)\end{array}$ & $\begin{array}{r}2.59 \\
(1.36) \\
\end{array}$ & $\begin{array}{c}2.48 \\
(0.85) \\
\end{array}$ & $\begin{array}{r}2.65 \\
(0.81) \\
\end{array}$ \\
\hline $\begin{array}{l}\text { D6 I find I am continually going over my school work in my mind at } \\
\text { times like when I am on the bus, walking or lying in bed, and so on. }\end{array}$ & & .31 & $\begin{array}{c}2.79 \\
(1.44)\end{array}$ & $\begin{array}{c}3.25 \\
(1.33)\end{array}$ & $\begin{array}{c}2.81 \\
(1.12)\end{array}$ & $\begin{array}{l}4.20 \\
(.89) \\
\end{array}$ & $\begin{array}{c}2.64 \\
(1.29)\end{array}$ & $\begin{array}{l}2.84 \\
(1.5)\end{array}$ & $\begin{array}{c}2.12 \\
(0.82)\end{array}$ & $\begin{array}{c}2.45 \\
(0.92)\end{array}$ \\
\hline $\begin{array}{l}\text { D7 I like to do enough work on a topic so that I can form my own } \\
\text { conclusions before I am satisfied. }\end{array}$ & & .61 & $\begin{array}{c}3.17 \\
(1.09)\end{array}$ & $\begin{array}{l}3.21 \\
(1.1)\end{array}$ & $\begin{array}{c}2.86 \\
(0.79)\end{array}$ & $\begin{array}{c}3.19 \\
(1.08)\end{array}$ & $\begin{array}{c}2.94 \\
(1.12)\end{array}$ & $\begin{array}{c}3.24 \\
(1.20)\end{array}$ & $\begin{array}{c}2.92 \\
(0.98)\end{array}$ & $\begin{array}{c}3.11 \\
(0.99)\end{array}$ \\
\hline Relating Ideas (Items = 2) & .56 & & & & & & & & & \\
\hline $\begin{array}{l}\text { D8 I try to relate what I have learned in one subject to what I learn in } \\
\text { other subjects. }\end{array}$ & & .51 & $\begin{array}{l}3.33 \\
(.96) \\
\end{array}$ & $\begin{array}{l}3.71 \\
(1.0) \\
\end{array}$ & $\begin{array}{c}3.29 \\
(0.96)\end{array}$ & $\begin{array}{c}3.76 \\
(0.89)\end{array}$ & $\begin{array}{c}3.30 \\
(1.19)\end{array}$ & $\begin{array}{c}3.81 \\
(1.12)\end{array}$ & $\begin{array}{c}2.70 \\
(0.94)\end{array}$ & $\begin{array}{c}3.14 \\
(0.90) \\
\end{array}$ \\
\hline D9 I like constructing theories to fit things together. & & .63 & $\begin{array}{c}3.00 \\
(1.14)\end{array}$ & $\begin{array}{c}3.42 \\
(1.21)\end{array}$ & $\begin{array}{c}3.0 \\
(1.26)\end{array}$ & $\begin{array}{c}3.62 \\
(1.16)\end{array}$ & $\begin{array}{c}2.48 \\
(0.97)\end{array}$ & $\begin{array}{r}3.06 \\
(1.29) \\
\end{array}$ & $\begin{array}{c}2.90 \\
(0.95)\end{array}$ & $\begin{array}{c}3.17 \\
(0.86) \\
\end{array}$ \\
\hline Understanding (Items = 2) & .62 & & & & & & & & & \\
\hline $\begin{array}{l}\text { D10 I try to relate new material, as I am reading it, to what I already } \\
\text { know on that topic. }\end{array}$ & & .53 & $\begin{array}{c}3.33 \\
(1.17)\end{array}$ & $\begin{array}{l}3.96 \\
(.95) \\
\end{array}$ & $\begin{array}{c}3.43 \\
(1.25)\end{array}$ & $\begin{array}{l}3.95 \\
(.97) \\
\end{array}$ & $\begin{array}{c}3.24 \\
(1.22) \\
\end{array}$ & $\begin{array}{c}3.81 \\
(1.12)\end{array}$ & $\begin{array}{c}3.00 \\
(1.01)\end{array}$ & $\begin{array}{c}3.18 \\
(0.85) \\
\end{array}$ \\
\hline $\begin{array}{l}\text { D11 When I read a textbook, I try to understand what the author } \\
\text { means. }\end{array}$ & & .49 & $\begin{array}{l}3.08 \\
(.97) \\
\end{array}$ & $\begin{array}{l}3.71 \\
(1.0)\end{array}$ & $\begin{array}{c}3.33 \\
(1.32)\end{array}$ & $\begin{array}{c}3.81 \\
(1.25)\end{array}$ & $\begin{array}{c}2.73 \\
(1.23)\end{array}$ & $\begin{array}{c}2.97 \\
(1.03)\end{array}$ & $\begin{array}{c}2.83 \\
(1.08)\end{array}$ & $\begin{array}{c}3.19 \\
(0.90) \\
\end{array}$ \\
\hline & & & $\begin{array}{c}2.91 \\
(0.62)\end{array}$ & $\begin{array}{c}3.37 \\
(0.49)\end{array}$ & $\begin{array}{l}2.92 \\
(.64) \\
\end{array}$ & $\begin{array}{c}3.54 \\
(0.70)\end{array}$ & $\begin{array}{l}2.77 \\
(0.61)\end{array}$ & $\begin{array}{c}3.13 \\
(0.65)\end{array}$ & $\begin{array}{c}2.76 \\
(0.52)\end{array}$ & $\begin{array}{c}3.03 \\
(0.59) \\
\end{array}$ \\
\hline $\begin{array}{l}\text { Comparison of pre- and post-PBL of } \\
\text { Deep Approach learning (Items }=11 \text { ) }\end{array}$ & & & $\begin{array}{r}t=-4 \\
\text { Sign }\end{array}$ & $\begin{array}{l}87, p= \\
00 \\
\text { ficant }\end{array}$ & $\begin{array}{r}t=-4 \\
.0 \\
\text { Signi }\end{array}$ & $\begin{array}{l}36, p= \\
00 \\
\text { ficant }\end{array}$ & $\begin{array}{r}\mathbf{t}=-4 . \\
31, \mathrm{p} \\
\text { Sign }\end{array}$ & $\begin{array}{l}\text { 8, } \mathrm{df}= \\
=.000 \\
\text { ficant }\end{array}$ & $\begin{array}{c}t=-5.9 \\
118, p \\
\text { Signif }\end{array}$ & $\begin{array}{l}\mathrm{df}= \\
.000: \\
\text { cant }\end{array}$ \\
\hline Surface Approach (Items = 11) & .75 & & & & & & & & & \\
\hline Fear of Failure (Items $=2)$ & .64 & & & & & & & & & \\
\hline $\begin{array}{l}\text { S1 I am discouraged by a poor mark on a test and worry about how } \\
\text { I will do on the next test. }\end{array}$ & & .35 & $\begin{array}{c}2.74 \\
(1.27) \\
\end{array}$ & $\begin{array}{c}3.12 \\
(1.36) \\
\end{array}$ & $\begin{array}{c}3.48 \\
(1.21) \\
\end{array}$ & $\begin{array}{c}3.20 \\
(1.24) \\
\end{array}$ & $\begin{array}{c}2.79 \\
(1.43) \\
\end{array}$ & $\begin{array}{c}3.22 \\
(1.50) \\
\end{array}$ & $\begin{array}{c}2.83 \\
(1.25) \\
\end{array}$ & $\begin{array}{r}2.62 \\
(1.09) \\
\end{array}$ \\
\hline $\begin{array}{l}\text { S2 Even when I have studied hard for a test, I worry that I may not } \\
\text { be able to do well in it. }\end{array}$ & & .66 & $\begin{array}{c}3.08 \\
(1.25) \\
\end{array}$ & $\begin{array}{l}3.33 \\
(1.2)\end{array}$ & $\begin{array}{r}3.71 \\
(1.27) \\
\end{array}$ & $\begin{array}{c}3.76 \\
(1.18)\end{array}$ & $\begin{array}{c}3.06 \\
(1.30) \\
\end{array}$ & $\begin{array}{c}3.34 \\
(1.33) \\
\end{array}$ & $\begin{array}{c}2.92 \\
(1.33)\end{array}$ & $\begin{array}{c}2.61 \\
(1.16)\end{array}$ \\
\hline Aim for Qualification (Items = 2) & .49 & & & & & & & & & \\
\hline $\begin{array}{l}\text { S3 Whether I like it or not, I can see that doing well in school is a } \\
\text { good way to get a well-paid job. }\end{array}$ & & .35 & $\begin{array}{c}2.5 \\
(1.22) \\
\end{array}$ & $\begin{array}{l}2.83 \\
(1.2)\end{array}$ & $\begin{array}{c}3.05 \\
(1.28) \\
\end{array}$ & $\begin{array}{l}3.24 \\
(1.3)\end{array}$ & $\begin{array}{c}2.76 \\
(1.32) \\
\end{array}$ & $\begin{array}{c}2.77 \\
(1.41)\end{array}$ & $\begin{array}{r}2.00 \\
(0.94) \\
\end{array}$ & $\begin{array}{c}2.55 \\
(1.01) \\
\end{array}$ \\
\hline $\begin{array}{l}\text { S4 I intend to get my A Levels because I feel that I will then be able } \\
\text { to get a better job. }\end{array}$ & & .43 & $\begin{array}{c}2.87 \\
(1.42) \\
\end{array}$ & $\begin{array}{c}2.71 \\
(1.23) \\
\end{array}$ & $\begin{array}{c}3.14 \\
(1.20) \\
\end{array}$ & $\begin{array}{c}3.24 \\
(1.37) \\
\end{array}$ & $\begin{array}{c}3.00 \\
(1.27) \\
\end{array}$ & $\begin{array}{c}3.16 \\
(1.30) \\
\end{array}$ & $\begin{array}{c}2.95 \\
(1.17) \\
\end{array}$ & $\begin{array}{c}3.13 \\
(1.05) \\
\end{array}$ \\
\hline Minimizing Scope of Study (Items $=4$ ) & .70 & & & & & & & & & \\
\hline $\begin{array}{l}\text { S5 I see no point in learning material which is not likely to be in the } \\
\text { examination. }\end{array}$ & & .54 & $\begin{array}{c}2.5 \\
(1.22) \\
\end{array}$ & $\begin{array}{l}2.58 \\
(1.14) \\
\end{array}$ & $\begin{array}{l}2.48 \\
(1.12) \\
\end{array}$ & $\begin{array}{c}2.24 \\
(1.26) \\
\end{array}$ & $\begin{array}{r}2.79 \\
(1.36) \\
\end{array}$ & $\begin{array}{c}3.25 \\
(1.41) \\
\end{array}$ & $\begin{array}{c}1.46 \\
(0.71) \\
\end{array}$ & $\begin{array}{c}1.99 \\
(0.93) \\
\end{array}$ \\
\hline $\begin{array}{l}\text { S6 As long as I feel I am doing enough to pass, I devote as little time } \\
\text { to studying as I can. There are many more interesting things to do. }\end{array}$ & & .55 & $\begin{array}{c}2.21 \\
(1.35) \\
\end{array}$ & $\begin{array}{c}2.12 \\
(1.36) \\
\end{array}$ & $\begin{array}{l}2.29 \\
(1.3) \\
\end{array}$ & $\begin{array}{c}2.33 \\
(1.43) \\
\end{array}$ & $\begin{array}{r}3.09 \\
(1.44) \\
\end{array}$ & $\begin{array}{c}3.23 \\
(1.48) \\
\end{array}$ & $\begin{array}{r}2.47 \\
(1.08) \\
\end{array}$ & $\begin{array}{c}2.49 \\
(0.96) \\
\end{array}$ \\
\hline $\begin{array}{l}\text { S7 I generally restrict my study to what is specifically set as I think it } \\
\text { is unnecessary to do anything extra. }\end{array}$ & & .59 & $\begin{array}{c}2.75 \\
(1.07) \\
\end{array}$ & $\begin{array}{l}3.04 \\
(1.3) \\
\end{array}$ & $\begin{array}{r}2.86 \\
(1.35) \\
\end{array}$ & $\begin{array}{c}2.76 \\
(1.18) \\
\end{array}$ & $\begin{array}{c}2.94 \\
(1.00) \\
\end{array}$ & $\begin{array}{c}3.28 \\
(1.11) \\
\end{array}$ & $\begin{array}{c}2.3 \\
(1.00) \\
\end{array}$ & $\begin{array}{c}2.49 \\
(0.87) \\
\end{array}$ \\
\hline $\begin{array}{l}\text { S8 I find it is not helpful to study topics in depth. You don't really } \\
\text { need to know much in order to get by in most topics. }\end{array}$ & & .62 & $\begin{array}{l}2.46 \\
(1.1) \\
\end{array}$ & $\begin{array}{c}2.96 \\
(1.37) \\
\end{array}$ & $\begin{array}{c}2.29 \\
(1.10) \\
\end{array}$ & $\begin{array}{c}2.33 \\
(1.15) \\
\end{array}$ & $\begin{array}{c}2.70 \\
(1.10) \\
\end{array}$ & $\begin{array}{c}2.91 \\
(1.14) \\
\end{array}$ & $\begin{array}{c}2.31 \\
(1.01) \\
\end{array}$ & $\begin{array}{l}2.38 \\
(0.97) \\
\end{array}$ \\
\hline Memorization (Items $=3$ ) & .65 & & & & & & & & & \\
\hline $\begin{array}{l}\text { S9 I learn some things by rote, going over and over them until I } \\
\text { know them by heart. }\end{array}$ & & .52 & $\begin{array}{c}2.87 \\
(1.15)\end{array}$ & $\begin{array}{l}3.04 \\
(1.4)\end{array}$ & $\begin{array}{l}2.76 \\
(.89) \\
\end{array}$ & $\begin{array}{c}3.00 \\
(1.05)\end{array}$ & $\begin{array}{c}2.85 \\
(1.25) \\
\end{array}$ & $\begin{array}{c}2.84 \\
(1.51)\end{array}$ & $\begin{array}{c}2.94 \\
(1.02)\end{array}$ & $\begin{array}{c}3.2 \\
(1.02) \\
\end{array}$ \\
\hline $\begin{array}{l}\text { S10 I find the best ways to pass examinations is to try to remember } \\
\text { answers to likely questions. }\end{array}$ & & .62 & $\begin{array}{l}2.00 \\
(.96) \\
\end{array}$ & $\begin{array}{l}2.33 \\
(.96) \\
\end{array}$ & $\begin{array}{c}2.43 \\
(1.21) \\
\end{array}$ & $\begin{array}{c}2.38 \\
(1.47) \\
\end{array}$ & $\begin{array}{c}3.00 \\
(1.25) \\
\end{array}$ & $\begin{array}{c}3.06 \\
(1.37) \\
\end{array}$ & $\begin{array}{c}2.97 \\
(1.06) \\
\end{array}$ & $\begin{array}{l}2.90 \\
(1.04) \\
\end{array}$ \\
\hline $\begin{array}{l}\text { S11 I find I can get by in most assessments by memorizing key } \\
\text { sections rather than trying to understand them. }\end{array}$ & & .60 & $\begin{array}{l}2.25 \\
(1.26) \\
\end{array}$ & $\begin{array}{l}2.25 \\
(1.15) \\
\end{array}$ & $\begin{array}{l}2.86 \\
(0.79) \\
\end{array}$ & $\begin{array}{c}2.76 \\
(1.22) \\
\end{array}$ & $\begin{array}{l}2.39 \\
1.00 \\
\end{array}$ & $\begin{array}{c}2.55 \\
(1.28) \\
\end{array}$ & $\begin{array}{c}2.64 \\
(1.11) \\
\end{array}$ & $\begin{array}{c}2.87 \\
(1.01) \\
\end{array}$ \\
\hline & & & $\begin{array}{c}2.59 \\
(0.85)\end{array}$ & $\begin{array}{l}2.97 \\
(0.81)\end{array}$ & $\begin{array}{l}2.81 \\
(0.46)\end{array}$ & $\begin{array}{c}2.8 \\
(0.62)\end{array}$ & $\begin{array}{l}2.83 \\
(.59)\end{array}$ & $\begin{array}{l}3.04 \\
(.57) \\
\end{array}$ & $\begin{array}{l}2.52 \\
(0.56)\end{array}$ & $\begin{array}{c}2.66 \\
(0.56) \\
\end{array}$ \\
\hline Means of SAs and SAs after excluding items S3 \& S4. & & & $\begin{array}{l}2.84 \\
(0.72)\end{array}$ & $\begin{array}{l}2.85 \\
(0.59)\end{array}$ & $\begin{array}{l}2.77 \\
(0.51)\end{array}$ & $\begin{array}{c}2.75 \\
(0.68)\end{array}$ & $\begin{array}{l}2.85 \\
(.73) \\
\end{array}$ & $\begin{array}{c}3.08 \\
(0.70)\end{array}$ & $\begin{array}{l}2.53 \\
(.61) \\
\end{array}$ & $\begin{array}{l}2.62 \\
(.61)\end{array}$ \\
\hline $\begin{array}{l}\text { Comparison of pre- and post-PBL of Surface Approach to } \\
\text { learning excluding items S3 \& S4 (Items = 9) }\end{array}$ & & & $\begin{array}{l}t=-0.13 \\
\text { Non- } s i\end{array}$ & $\begin{array}{l}8, p=.89 \\
\text { gnificant }\end{array}$ & $\begin{array}{l}t=0.11 \\
\text { Non- si }\end{array}$ & $\begin{array}{l}\mathrm{p}=.91 \\
\text { gnificant }\end{array}$ & $\begin{array}{r}t=-2.85 \\
p= \\
\text { Sign }\end{array}$ & $\begin{array}{l}\mathrm{df}=31 \text {, } \\
008 \\
\text { ficant }\end{array}$ & $t=-1.9$ & ificant \\
\hline
\end{tabular}

\section{Views on collaboration}

The exploratory factor analysis of the 12 questionnaire items reported one factor accounting for $45.7 \%$ of the variances. Cronbach's alpha of views on collaboration is .89 , indicating a good scale of reliability of the measure (see Table 3 for details). 
Table 3. Views on Collaboration Results

\begin{tabular}{|c|c|c|c|c|c|c|c|c|c|}
\hline \multirow[b]{2}{*}{$\begin{array}{l}\text { Collaborative knowledge building } \\
\text { (Cronbach } \alpha=.89 \text { ) }\end{array}$} & \multirow[b]{2}{*}{$\begin{array}{c}\text { Factor } \\
\text { Loading }\end{array}$} & \multicolumn{2}{|c|}{$\begin{array}{c}\text { Class 1: Qatar_2 } \\
n=24\end{array}$} & \multicolumn{2}{|c|}{$\begin{array}{c}\text { Class 2: Qatar_1 } \\
n=21\end{array}$} & \multicolumn{2}{|c|}{$\begin{array}{c}\text { Class 3: Qatar_3 } \\
n=33\end{array}$} & \multicolumn{2}{|c|}{$\begin{array}{l}\text { Class 4: China } \\
n=120\end{array}$} \\
\hline & & pre & Post & pre & post & pre & post & pre & post \\
\hline $\begin{array}{l}\text { C1 We work on improving our ideas } \\
\text { continually during the process of inquiry }\end{array}$ & 0.66 & $\begin{array}{l}3.08 \\
(.78) \\
\end{array}$ & $\begin{array}{l}3.71 \\
(.83) \\
\end{array}$ & $\begin{array}{c}2.90 \\
(0.89) \\
\end{array}$ & $\begin{array}{c}3.95 \\
(0.92) \\
\end{array}$ & $\begin{array}{c}2.91 \\
(1.07) \\
\end{array}$ & $\begin{array}{c}3.69 \\
(1.17) \\
\end{array}$ & $\begin{array}{c}3.77 \\
(0.84) \\
\end{array}$ & $\begin{array}{c}3.95 \\
(0.79) \\
\end{array}$ \\
\hline $\begin{array}{l}\text { C2 Our views and knowledge broaden } \\
\text { through working with others. }\end{array}$ & 0.70 & $\begin{array}{c}2.92 \\
(1.02)\end{array}$ & $\begin{array}{c}3.79 \\
(0.93) \\
\end{array}$ & $\begin{array}{c}3.05 \\
(1.16) \\
\end{array}$ & $\begin{array}{c}4.29 \\
(0.72)\end{array}$ & $\begin{array}{c}3.39 \\
(1.19)\end{array}$ & & $\begin{array}{c}3.98 \\
(0.76) \\
\end{array}$ & $\begin{array}{l}3.98 \\
(0.75) \\
\end{array}$ \\
\hline $\begin{array}{l}\text { C3 Ideas from different members are } \\
\text { synthesized into new knowledge. }\end{array}$ & 0.70 & $\begin{array}{l}3.42 \\
(1.1) \\
\end{array}$ & $\begin{array}{l}3.70 \\
(4.0) \\
\end{array}$ & $\begin{array}{c}3.14 \\
(1.11) \\
\end{array}$ & $\begin{array}{l}4.33 \\
(0.58) \\
\end{array}$ & $\begin{array}{c}3.91 \\
(0.95) \\
\end{array}$ & & $\begin{array}{c}3.65 \\
(0.90) \\
\end{array}$ & $\begin{array}{l}3.87 \\
(0.79) \\
\end{array}$ \\
\hline $\begin{array}{l}\text { C4 Class members pose different ideas } \\
\text { with diverse perspectives. }\end{array}$ & 0.64 & $\begin{array}{l}3.00 \\
(.98)\end{array}$ & $\begin{array}{c}3.37 \\
(1.21) \\
\end{array}$ & $\begin{array}{c}3.24 \\
(0.83) \\
\end{array}$ & & & & $\begin{array}{c}3.85 \\
(0.87) \\
\end{array}$ & \\
\hline $\begin{array}{l}\text { C5 Ideas from different class members are } \\
\text { equally valuable. }\end{array}$ & 0.49 & $\begin{array}{l}2.87 \\
(0.95) \\
\end{array}$ & $\begin{array}{c}3.21 \\
(1.28) \\
\end{array}$ & $\begin{array}{c}2.95 \\
(1.16) \\
\end{array}$ & & $\begin{array}{r}3.09 \\
(1.21) \\
\end{array}$ & $\begin{array}{c}3.1 \\
(1.4) \\
\end{array}$ & & \\
\hline $\begin{array}{l}\text { C6 Goal setting and planning for our } \\
\text { progress is important. }\end{array}$ & 0.78 & $\begin{array}{c}3.58 \\
(1.28)\end{array}$ & & & & & & $\begin{array}{l}4.15 \\
(0.76) \\
\end{array}$ & \\
\hline $\begin{array}{l}\text { C7 Ideas are exchanged to improve our } \\
\text { knowledge. }\end{array}$ & 0.76 & & $\begin{array}{c}4.04 \\
(1.08) \\
\end{array}$ & & & & & $\begin{array}{l}4.20 \\
(0.82) \\
\end{array}$ & \\
\hline $\begin{array}{l}\text { C8 We reflect on and assess the progress } \\
\text { of our understanding continually. }\end{array}$ & 0.75 & $\begin{array}{r}3.25 \\
(1.03) \\
\end{array}$ & $\begin{array}{c}3.92 \\
(1.06) \\
\end{array}$ & $\begin{array}{l}3.19 \\
(0.93) \\
\end{array}$ & $\begin{array}{l}4.05 \\
(0.92) \\
\end{array}$ & $\begin{array}{c}3.61 \\
(1.20) \\
\end{array}$ & & $\begin{array}{l}3.68 \\
(0.93) \\
\end{array}$ & $\begin{array}{c}3.74 \\
(0.86) \\
\end{array}$ \\
\hline $\begin{array}{l}\text { C9 Different groups can benefit each other } \\
\text { and make progress together. }\end{array}$ & 0.64 & $\begin{array}{c}3.37 \\
(1.01)\end{array}$ & $\begin{array}{c}3.92 \\
(1.02) \\
\end{array}$ & $\begin{array}{c}3.14 \\
(1.23) \\
\end{array}$ & $\begin{array}{c}3.67 \\
(1.31) \\
\end{array}$ & $\begin{array}{c}3.73 \\
(1.28) \\
\end{array}$ & $\begin{array}{c}4.19 \\
(1.28) \\
\end{array}$ & $\begin{array}{l}3.91 \\
(0.96) \\
\end{array}$ & $\begin{array}{l}3.78 \\
(0.87)\end{array}$ \\
\hline $\begin{array}{l}\text { C10 Different sources of reference } \\
\text { information are examined for building } \\
\text { knowledge. }\end{array}$ & 0.70 & $\begin{array}{l}3.42 \\
(.97)\end{array}$ & $\begin{array}{c}4.00 \\
(0.83)\end{array}$ & $\begin{array}{c}3.43 \\
(0.98)\end{array}$ & $\begin{array}{c}4.10 \\
(1.00)\end{array}$ & $\begin{array}{c}3.64 \\
(1.17)\end{array}$ & $\begin{array}{c}3.97 \\
(1.09)\end{array}$ & $\begin{array}{c}3.44 \\
(0.92)\end{array}$ & $\begin{array}{c}3.47 \\
(0.83) \\
\end{array}$ \\
\hline $\begin{array}{l}\text { C11The knowledge we work on is relevant } \\
\text { to real-life problems. }\end{array}$ & 0.60 & $\begin{array}{c}3.83 \\
(1.00) \\
\end{array}$ & $\begin{array}{c}4.42 \\
(0.93) \\
\end{array}$ & $\begin{array}{c}3.57 \\
(1.03) \\
\end{array}$ & $\begin{array}{l}4.48 \\
(0.75) \\
\end{array}$ & $\begin{array}{c}3.18 \\
(1.01) \\
\end{array}$ & $\begin{array}{c}3.75 \\
(1.22) \\
\end{array}$ & $\begin{array}{c}3.12 \\
(0.86) \\
\end{array}$ & $\begin{array}{l}3.48 \\
(0.78) \\
\end{array}$ \\
\hline $\begin{array}{l}\text { C12 Our ideas and knowledge are relevant } \\
\text { within and outside the school context. }\end{array}$ & 0.63 & $\begin{array}{c}3.42 \\
(1.10)\end{array}$ & $\begin{array}{c}4.29 \\
(0.86) \\
\end{array}$ & $\begin{array}{c}3.43 \\
(1.12) \\
\end{array}$ & $\begin{array}{l}4.19 \\
(0.98)\end{array}$ & $\begin{array}{l}3.39 \\
(1.3) \\
\end{array}$ & $\begin{array}{c}3.75 \\
(1.34) \\
\end{array}$ & $\begin{array}{c}3.31 \\
(0.99) \\
\end{array}$ & $\begin{array}{l}3.44 \\
(0.96) \\
\end{array}$ \\
\hline & & $\begin{array}{l}3.28 \\
(0.8)\end{array}$ & $\begin{array}{c}3.91 \\
(0.68) \\
\end{array}$ & $\begin{array}{c}3.27 \\
(0.64) \\
\end{array}$ & $\begin{array}{l}4.22 \\
(0.48)\end{array}$ & $\begin{array}{l}3.56 \\
(0.76) \\
\end{array}$ & $\begin{array}{c}3.89 \\
(0.91) \\
\end{array}$ & $\begin{array}{l}3.76 \\
(0.53) \\
\end{array}$ & $\begin{array}{l}3.86 \\
(0.55) \\
\end{array}$ \\
\hline $\begin{array}{l}\text { Comparison of pre- and post-PBL for } \\
\text { views on collaboration ( } 12 \text { items) }\end{array}$ & & & $\begin{array}{l}2, p= \\
00 \\
\text { ficant }\end{array}$ & SIS & $=.000$ & 5 & $=.006$ & 5 & $\begin{array}{l}p=.02 \\
\text { cant }\end{array}$ \\
\hline
\end{tabular}

As Table 3 shows, the results indicate that students from all four classes reported a significant increase of their views on the value of collaboration after having competed a PBL course (Class 1: $\mathrm{t}=-4.32, \mathrm{p}=.000, \mathrm{Class} 2: \mathrm{t}=$ 6.12, $\mathrm{p}=.000$, Class 3: $\mathrm{t}=-2.96, \mathrm{p}=.006$, Class $4: \mathrm{t}=-2.42, \mathrm{p}=.02$ ).

\section{Co-relation between approach to learning and views on collaboration}

The study examined correlations between measuring learning approaches and views on collaboration. The results indicate that students' views on collaboration correlate significantly with the deep approach $(\mathrm{r}=.52$, $\mathrm{p}<0.01)$. No significant correlation was found between collaboration and the surface approach $(r=.12, \mathrm{p}=.096)$.

\section{Qualitative Findings}

This section analyzes the findings of engineering students' first experiences with and perceptions of PBL.

\section{Benefits of PBL}

During group interviews, students were asked to discuss the experiences they had throughout the project process, namely starting the project, setting goals, implementing learning strategies, dealing with the challenges they encountered, and using coping strategies, as well as the learning benefits they had gained from both group and individual perspectives. A summary of the 37 group interviews that were carried out with a total of 188 participants found general alignment with the survey results in that students possessed an awareness and appreciation of developing deep learning through team projects. The thematic analysis of the results from all four classes found perceived benefits in the following categories.

First, the most noted benefits were improved interest and motivation. All of the 37 groups reported an increased interest in the subject when working on a project that they believed to be relevant to engineering practice. Dealing with hands-on skills also helped them feel more self-confident and make sense of the engineering contents. Students from one group agreed, 
A project makes the subject much more interesting and we are motivated. Lack of motivation is a major issue for college students nowadays. (Group 2, Class 4)

Secondly, other benefits mentioned were responsibility and commitment to study. The majority of the students (mentioned by all of the groups) reported a strong sense of responsibility when they worked on projects, despite the difficulty of conducting an engineering project. They were highly engaged and spent significant amounts of time outside of school working on the projects. One group reported:

When we work on a project chosen by ourselves, we know our future work may look like this; it is so exciting that we spend two or three as much times as just going to lectures. We meet several times a week, and every night on WhatsApp. When there are troubles, we have to solve it right away. (Group 4, Class 2)

However, the aspect of responsibility and commitment was reported by students in Classes 2 and 3 right from the beginning of the course, and this may have been because they formed the team on their own. Classes 1 and 4 experienced a period of confusion before they found a way to engage with a PBL method. The longer transition time in Class 1 may have been due to the fact that their teams were suggested by the instructor and it took time for the students to get to know each other. In Class 4, the large class size (120 students) and the number of groups (10) may have contributed to more time being needed for team building.

Along with the two benefits mentioned above, students also reported an increased appreciation of deep learning through projects addressing different aspects. All groups of students in Classes 1, 2, and 3 from Qatar highlighted PBL's contribution to their abilities to "apply theories to practice", "better understand engineering practice", and "make sense of lectures." Five groups in Class 3 (Groups 1, 2, 3, 5, 7) mentioned that assistance from industry external experts helped them to reach a deep understanding of real-life application. Students from Class 4 from China mostly discussed gaining a "better understanding of the theories through application to practice."

In addition, around two-thirds of the students $(n=110)$ from each class described benefits of learning from teamwork. Some groups (Groups 2, 5 from Class 1; Groups 1, 5 from Class 2; Groups 1, 3, 4 from Class 3; and Group $2,4,9,11$ from Class 4 ) reported teamwork as a beneficial way to set high goals. One group said:

On our team, we are ambitious; we want to get an A, so we work hard together and help each other to reach our goals. (Group 2, Class 1).

Two groups (Group 3 from Class 2, Group 5 from Class 3) also mentioned how low academic achievers seemed to benefit from teamwork. One said:

We are a group of students who aimed to just pass at the beginning, but suddenly we felt on the right track and adjusted our goal for higher achievement. (Group 3, Class 2).

\section{Challenges}

Keeping in mind that transitioning from lecture-based learning to a PBL environment may generate confusion and obstacles, another focus of the interviews was to invite students from the same project team to reflect together on what challenges they encountered. This information could be used to explain the sustaining use of surface learning and determine what coping strategies they developed.

Students identified a few challenges in their initial experience with PBL, which may also provide clues to why surface learning remained the same or even increased in Class 3.

Firstly, nearly all students $(n=162)$ expressed their feeling of insecurity due to a lack of understanding of what a problem should be and how to tackle a project at the beginning. They also cited a lack of prior experiences and skills in addition to reflecting on a learning-by-doing approach to develop project skills throughout their first experience. One group recalled:

This was the first time we did a real project; before, the so-called project lasted one- two weeks and only accounted for $15 \%$ of our grade. This time the project accounted for $70 \%$ of time. We were excited for such a big project but also worried how we would manage it in a mostly beneficial way and how we could get good grades. We believe that next time we will do much better than this project because we have learned many new skills. (Group 1, Class 2).

Grades and exams were also frequently cited concerns for a variety of reasons. In Class 1, five out of the six groups (except Group 2) reported their fear of failing to reach their goals in final grades, which may also be related to their feeling of insecurity when working in appointed teams. Most groups worried about whether they would 
be able to reach the curriculum objectives. Of the four groups, Classes 2 and 3 had the fewest concerns about passing exams. However, the groups that had the highest ambitions were concerned about how their additional effort put toward project work would lead to good grades. The majority of students in Class 4 reported confusion about the exam, which is also related to their general lack of PBL experiences regarding its intention and purpose. At the beginning of the course, all groups cited a lack of understanding of how the exam would be designed. Although project grades accounted for $60 \%$ of their final grades, as one student said, I could not "imagine what a project report made by a team would look like and how it would be fairly graded."

The challenges of team dynamics were addressed by two groups in Classes 2 and 3, and by most groups in Classes 1 and 4 . Working in appointed teams, five out of six of the groups in Class 1 experienced confusion around how to build a team and reach consensus on project goals and strategies. In Class 4, all of the groups reflected upon their lack of communication and team skills, and as one group mentioned, "lots of time was wasted in trying to guess what each other meant to the team" (Group 3). They all discussed that if they would have had better teamworking skills, they felt they would have benefited much more from the project work. Related to the team dynamic issues, fairness regarding grades for team projects was also discussed in all group interviews. Approximately half the students in each class supported having all of the group members receive the same grade while the other half of the class felt receiving individual grades were fairer. For all students, clarifying a convincing procedure and criteria for team grades from the start of the project was suggested to be an essential matter.

Furthermore, students had several concerns related to incorporating PBL into the current institutional environment of their studies. For example, all of the groups in Classes 1, 2, and 3 from Qatar reported the project workload being a major challenge, in particular in the late stage of the semester. One group said:

We had four subjects this semester, and each subject has four- five types of assignments and exams. The last two months of the semester were full of deadlines, which made it so hard to stay caught up on the project as we had wished even though we didn't like it. (Group 3, Class 2)

Although Chinese students from Class 4 did not complain about the burdens of student life, they mentioned their busy schedules of college life-constant campus activities such as competitions, clubs, and volunteer work, among others - in addition to a heavy academic schedule, which meant they could only meet for project work on the weekends. These time-related challenges represented hurtles that hindered students in reaching their goals and ambitions. Access to information also limited the scope of their projects; for example, while students from Classes 1, 2, and 3 in Qatar had difficulty accessing certain software to be used for their engineering design, Chinese students from Class 4 reported limitations in being able to obtain information from companies or relevant public sectors. This may be due to a less developed collaborative tradition between the universities and the broader community in China.

\section{Coping strategies}

All students in the study felt time constraints in working on a project within the scope of the course where PBL was implemented, and they developed strategies to "survive," all of which were related to surface learning (Biggs \& Tang, 2011; Kember, Biggs, \& Leugn, 2004). First, approximately two thirds of the groups in each class found that they had to reduce their ambitions by minimizing their projects' scope because of time limitations. As one group said, "we have many assignments to submit in the last month of the semester in our four courses, sometimes we cannot keep track of the deadlines, so we have had to limit our ambitions and just survive" (Group 4, Class 3).

Another coping strategy students used was seeking external help when they had trouble and things got difficult. All groups mentioned that they would turn to the course instructor to get "the correct" answers to ensure their project was on the right track. In addition, Chinese students from 16 out of 20 groups in Class 4 mentioned that they chose to survive by finding ways to ensure individual learning and divide the group learning tasks among the members, coming up with a compilation of each other's contributions as a final collaborative work. As some mentioned,

Time passes so fast, suddenly the course is about to finish, and we didn't have any more time to solve our team issues but just look past over it. We just had to divide the tasks to get them done. It was important for us to work on our individual learning for our final grades. (Group 10).

Similar strategies were also used by two groups in Class 1, one group in Class 2, and two groups in Class 3 for the same reasons: to ensure good final individual grades. 


\section{DISCUSSION AND CONCLUSION}

This study aimed to investigate engineering students' approaches to learning and views on collaboration after their first experience with a PBL environment at the course level. We explored whether the students evolve their learning approaches and if their collaboration values changed. Both the quantitative and qualitative data revealed that students from all four engineering classes significantly improved their deep learning strategies and valued teamwork more after participating in a course that required a team project. This result contributes to the current literature on approaches to learning in higher education, an arena wherein ambiguous results have been reported; some researchers have reported stability and others have suggested a dynamic nature that changes over time (Postareff, Parpala, \& Lindblom-Ylänne, 2015). This study has reported valid and reliable results, which represents a significant difference between previous studies on approaches to learning that were conducted with Bigg's framework, and so far, no consistency has been found with empirical evidence (Asikainen \& Gijbels, 2017). In addition, this study's qualitative data explored the association between increased deep learning and PBL benefits as perceived by students. The outcome of the analysis shows that PBL characteristics recognized in engineering education can be related to the adaptation of deep strategies; for example, working on team projects motivates students to develop a sense of responsibility through having them navigate the project management process (Du, Su, \& Liu, 2013; Lehmann, Christensen, Du, \& Thrane, 2008; Zhao, Zhang, \& Du, 2018), allowing them delve into the content, and moving them from a level of knowing something to having a deep understanding and application of it (Dochy, Segers, Bossche, \& Gijbels, 2003; Kolmos \& Graaff, 2014; Strobel \& Van Barneveld, 2009), thus developing the professional identity of becoming an engineer (Magnell, Geschwind, \& Kolmos, 2017).

With empirical evidence from engineering students, this study confirms what Dolmans, Loyens, Marcq, and Gijbels (2016) concluded in their review of the health science literature: that PBL enhances deep learning (although stronger evidence is needed) while having little influence on surface learning. Three classes in the current study reported no decrease and one class exhibited an increase in surface learning. The qualitative data of the study further explored the reasons and factors that may have contributed to the underpinning use of surface learning. First, there is the students' lack of prior experience and deep understanding of PBL. Despite efforts taken by instructors to communicate with students about the rationale and objectives for using PBL, students in the study reported a limited understanding of PBL as well as unclear goals and potential outcomes. For many students, PBL was a radical shift in how they understood their education, and they were insecure in this new context, meaning they may have adopted surface approaches to learning (Prosser \& Sze, 2014). Therefore, it is necessary for the instructor to have a sophisticated understanding of PBL and there must be ongoing support for students to develop a deeper understanding of PBL. Second, assessment methods were regarded as one of the major factors that prevented a decrease in surface learning (Baeten, Kyndt, Struyven, \& Dochy, 2010; Dolmans, Loyens, Marcq, \& Gijbels, 2016). While students tended to employ deep learning approaches when preparing their assignment essays, things which are perceived as assessing higher levels of cognitive processing, if the focus of learning is on passing examinations aimed at testing short-term retention, then traditional methods of teaching are favored (Entwistle, 2009; Scouller, 1998). As Entwistle (2009) suggested, deep processing could be changed to surface processing if the task comprises activities requiring short-term retention, such as answering multiple-choice questions, for example. In a PBL environment, assessment should favor long-term retention of information, as well as non-knowledgebased and skill-based assessments, instead of the short-term retention of new information which is favored by traditional teaching and surface learning approaches (Prosser \& Sze, 2014).

If it is anticipated that a PBL environment serves as a driving factor for students to value collaboration in teamwork, then this study serves as evidence. This can be explained by the characteristics of PBL and can also be recognized as an effect of facilitating collaborative teamwork skills (Borrego, Karlin, McNair, \& Beddoes, 2013; Hmeo-Silver, 2012; Magnell, Geschwind, \& Kolmos, 2017; Prince \& Felder, 2006). Challenges in teamwork identified in the qualitative findings revealed that there is a need to support students with teamwork skills when they have not had any prior experiences or tradition with working in groups (Saravanamuthu \& Yap, 2014). Implementing PBL at the course level with limited time and space is particularly challenging to addressing this concern.

Furthermore, the outcome of the study provides evidence supporting the positive relationship between students' adopting the deep learning approach and their valuing collaboration in teamwork, indicating that students who prefer a deep approach to learning are more motivated to engage in collaborative teams (Chan \& Chan, 2011). This finding indicates that further efforts on engaging students with PBL may benefit both deep learning and team effectiveness, which are highly valued by engineering programs (Beddoes, Jesiek, \& Borrego, 2010; Borrego, Karlin, McNair, \& Beddoes, 2013).

In addition, due to the fundamental assumption that approaches to learning are context-specific by classes (Bigg \& Tang, 2011; Entwistle, 2009), four different engineering courses at an initial stage of implementing PBL were used for data generation in this study. While improved deep learning and views on collaboration were identified in all four of the classes, the results on surface learning were varied, with three classes reporting no changes and one reporting an increase. This may be related to how each individual instructor implements PBL, to student variation 
in each class, or to students' interest in the course contents (Case \& Marshall, 2004). The results indicate a need for future studies that help determine a common understanding of implementing PBL at the course level-what are the principles, indicators, and strategies-aspects that can be related to fidelity concerns for a successful implementation of PBL (Hmeo-Silver, 2012).

Overall curriculum standards instructors must follow while implementing PBL can be seen as a limitation since these will affect the amount of time they can spend providing the necessary support to the students (Al Said, Du, ALKhatib, Romanowski, \& Barham, 2019). Thus, while PBL is increasingly being implemented at a course level, challenges arise from an institutional perspective, such as how to adjust assessment policy to constructively align with the PBL objectives (Biggs \& Tang, 2011), how to provide facilities for such a learning environment (i.e., classrooms, materials, and maintaining balance with other courses), and how to maintain a balance between reaching the required outcome of the curriculum and the content outcome of the project while facilitating the necessary skills to maximize learning in PBL (Hmelo-Silver \& Barrows, 2006).

This study has a few significant takeaways as well as a few limitations. First, although the study provides insights into the PBL beginners' experiences concerning learning approaches and collaboration, the results of the study remain provisional because learners may change their strategies and perceptions when they gain more experience in PBL environments. Therefore, further longitudinal studies to observe students' growth and development would be meaningful. In addition, while this research design offered an opportunity to gain insight into how students report their approaches to learning and views on collaboration at the course level of PBL implementation, we did not investigate the possibilities of students' developing various strategies across different courses or comparing their responses between PBL and non-PBL settings, which deserves further research attention. Further studies could compare students' approaches to learning across different courses with different teaching and learning methods to better understand the social and cultural factors at play. Moreover, although the study filled in the field's methodological and empirical research gap (Postareff, Parpala, \& Lindblom-Ylänne, 2015) by yielding longitudinal data in both quantitative and qualitative forms, the multiple sources of data are primarily self-reported. Although the respondent rate of the study is $92 \%$ for survey and $87 \%$ for interviews, there is still a possibility that those who did not participate in the study held different opinions toward PBL and teamwork. Evidence from other sources, such as observations, may be used in future studies to compare self-reported data results. Although the four courses in the study implemented PBL following same principles and with the support of the same facilitator, there may have been diverse contextual reasons that potentially influenced the process of implementation and results of student development. However, despite the limitations, this study builds upon the literature on student approaches to learning and collaboration and contributes to research on student learning in higher education, particularly as concerns PBL and engineering education, by investigating interactions among the concepts. The study also provides research evidence for initial practices of implementing PBL at a course level in a bottom-up form. Results of the study contribute to literature in the field of pedagogical change in sociocultural contexts that favor lecture-based teaching methods, providing evidence of benefits and obstacles to changes. The detailed analysis and practical suggestions not only provide implications for the context of engineering education in Qatar and China, but also to any educational context initiating educational change to PBL and beyond.

\section{REFERENCES}

Al Said, R. S., Du, X., ALKhatib, H. A. H., Romanowski, M. H., \& Barham, A. I. I. (2019). Math Teachers' Beliefs, Practices, and Belief Change in Implementing Problem Based Learning in Qatari Primary Governmental School. EURASIA Journal of Mathematics, Science and Technology Education, 15, 5. https:/ / doi.org/10.29333/ ejmste/105849

Asikainen, H., \& Gijbels, D. (2017). Do students develop towards more deep approaches to learning during studies? A systematic review on the development of students' deep and surface approaches to learning in higher education. Educational Psychology Review, 29(2), 205-234. https:/ / doi.org/10.1007/s10648-017-9406-6

Baeten, M., Kyndt, E., Struyven, K., \& Dochy, F. (2010). Using student-centred learning environments to stimulate deep approaches to learning: Factors encouraging or discouraging their effectiveness. Educational Research Review, 5(3), 243-260. https:/ / doi.org/10.1016/j.edurev.2010.06.001

Beddoes, K. D., Jesiek, B. K., \& Borrego, M. (2010). Identifying opportunities for collaborations in international engineering education research on problem-and project-based learning. Interdisciplinary Journal of Problembased Learning, 4(2), 3. https:/ / doi.org/10.7771/1541-5015.1142

Biggs, J. B. \& Tang, C. (2011). Teaching for quality learning at university: What the student does. McGraw-Hill Education (UK).

Borrego, M., Karlin, J., McNair, L. D., \& Beddoes, K. (2013). Team effectiveness theory from industrial and organizational psychology applied to engineering student project teams: A research review. Journal of Engineering Education, 102(4), 472-512. https:/ / doi.org/10.1002/jee.20023 
Case, J., \& Marshall, D. (2004). Between deep and surface: procedural approaches to learning in engineering education contexts. Studies in Higher Education, 29(5), 605-615. https:/ / doi.org/10.1080/0307507042000261571

Chan, C. K., \& Chan, Y. Y. (2011). Students' views of collaboration and online participation in Knowledge Forum. Computers $\mathcal{E}$ Education, 57(1), 1445-1457. https:/ / doi.org/10.1016/j.compedu.2010.09.003

Chiocchio, F., \& Essiembre, H. (2009). Cohesion and performance: A meta-analytic review of disparities between project teams, production teams, and service teams. Small Group Research, 40(4), 382-420. https:/ / doi.org/10.1177/1046496409335103

Cohen, L., Manion, L., \& Morrison, K. (2013). Research methods in education. Routledge. https:/ / doi.org/10.4324/9780203720967

Creswell, J. W., \& Clark, V. L. P. (2017). Designing and conducting mixed methods research. Sage Publications.

De Clercq, M., Galand, B., \& Frenay, M. (2013). Chicken or the egg: longitudinal analysis of the causal dilemma between goal orientation, self-regulation and cognitive processing strategies in higher education. Studies in Educational Evaluation, 39(1), 4-13. https:/ / doi.org/10.1016/j.stueduc.2012.10.003

Dinsmore, D., \& Alexander, P. A. (2012). A critical discussion of deep and surface processing: what it means, how it is measured, the role of context, and model specification. Educational Psychology Review, 24(4), 499-567. https:// doi.org/10.1007/s10648-012-9198-7

Dochy, F., Segers, M., Van den Bossche, P., \& Gijbels, D. (2003). Effects of problem-based learning: A meta-analysis. Learning and Instruction, 13(5), 533-568. https:/ / doi.org/10.1016/S0959-4752(02)00025-7

Dolmans, D., Loyens, S., Marcq, H., \& Gijbels, D. (2016). Deep and surface learning in problem-based learning: a review of the literature. Advances in Health Science Education, 21(5), 1087-1112. https:/ / doi.org/10.1007/s10459-015-9645-6

Du, X., Cyprian, F. S., Kassab, S. E., Al-Moslih, A. M., Abu-Hijleh, M. F., \& Hamdy, H. (2019). Identifying essential competencies for medical schools. Journal of Applied Research in Higher Education. https:/ / doi.org/10.1108/JARHE-07-2018-0114

Du, X., Emmersen, J., Toft, E., \& Sun, B. (2013). PBL and Critical Thinking Disposition in Chinese Medical Students-A Randomized Cross-Sectional Study. Journal of problem based Learning in Higher Education, 1(1), 72-83.

Du, X., Massoud, W., Al-Banna, N. A., Al-Moslih, A. M., Abu-Hijleh, M. F., Hamdy, H., \& Cyprian, F. S. (2016). Preparing foundation-year students for medical studies in a problem-based learning environment: Students' perceptions. Health Professions Education, 2(2), 130-137. https:/ / doi.org/10.1016/j.hpe.2016.06.001

Du, X., Su, L., \& Liu, J. (2013). Developing sustainability curricula using the PBL method in a Chinese context. Journal of Cleaner Production, 61, 80-88. https:/ / doi.org/10.1016/j.jclepro.2013.01.012

Entwistle, N. (2009). Teaching for understanding at university. Deep approaches and distinctive ways of thinking. England: Palgrave Macmillan. https:/ / doi.org/10.1007/978-1-137-09106-2

Entwistle, N. J. (1991). Approaches to learning and perceptions of the learning environment. Higher Education, 22(3), 201-204. https://doi.org/10.1007/BF00132287

Felder, R. M., \& Brent, R. (2003). Designing and teaching courses to satisfy the ABET engineering criteria. Journal of Engineering Education, 92(1), 7-25. https:// doi.org/10.1002/j.2168-9830.2003.tb00734.x

He, Y., Du, X., Toft, E., Zhang, X., Qu, B., Shi, J., ... \& Zhang, H. (2018). A comparison between the effectiveness of PBL and LBL on improving problem-solving abilities of medical students using questioning. Innovations in Education and Teaching International, 55(1), 44-54. https:/ / doi.org/10.1080/14703297.2017.1290539

Heikkilä, A., \& Lonka, K. (2006). Studying in higher education: students' approaches to learning, self-regulation, and cognitive strategies. Studies in Higher Education, 31(1), 99-117. https:/ / doi.org/10.1080/03075070500392433

Helle, L., Tynjälä, P., \& Olkinuora, E. (2006). Project-based learning in post-secondary education-theory, practice and rubber sling shots. Higher Education, 51(2), 287-314. https:/ / doi.org/10.1007/s10734-004-6386-5

Hmelo-Silver, C. E. (2012). International perspectives on problem-based learning: Contexts, cultures, challenges, and adaptations. Interdisciplinary Journal of Problem-Based Learning, 6(1), 3. https://doi.org/10.7771/15415015.1310

Hmelo-Silver, C. E., \& Barrows, H. S. (2006). Goals and Strategies of a Problem-based Learning Facilitator. Interdisciplinary Journal of Problem-Based Learning, 1(1). https:/ / doi.org/10.7771/1541-5015.1004

Kember, D., Biggs, J., \& Leung, D. Y. (2004). Examining the multidimensionality of approaches to learning through the development of a revised version of the Learning Process Questionnaire. British Journal of Educational Psychology, 74(2), 261-279. https:// doi.org/10.1348/000709904773839879 
Kolmos, A., \& de Graaff, E. (2014). Problem-based and project-based learning in engineering education: merging models. In A. Johri, \& B. M. Olds (Eds.), Cambridge Handbook of Engineering Education Research (pp. 141-161). Cambridge University Press.

Kvale, S., \& Brinkmann, S. (2009). Interview. Hans Reitzel.

Lehmann, M., Christensen, P., Du, X., \& Thrane, M. (2008). Problem-oriented and project-based learning (POPBL) as an innovative learning strategy for sustainable development in engineering education. European journal of engineering education, 33(3), 283-295. https:/ / doi.org/10.1080/03043790802088566

Loyens, S. M. M., Gijbels, D., Coertjens, L., \& Cote', D. (2013). Students' approaches to learning in problem-based learning: Taking into account students' behavior in the tutorial groups, self-study time, and different assessment aspects. Studies in Educational Evaluation, 39(1), 23-32. https:/ / doi.org/10.1016/j.stueduc.2012.10.004

Magnell, M., Geschwind, L., \& Kolmos, A. (2017). Faculty perspectives on the inclusion of work-related learning in engineering curricula. European Journal of Engineering Education, 42(6), 1038-1047. https:/ / doi.org/10.1080/03043797.2016.1250067

Marton, F. \& Saljo, R. (1976a). On qualitative differences in learning: I-outcome and process. British Journal of Educational Psychology, 46, 4-11. https:/ / doi.org/10.1111/j.2044-8279.1976.tb02980.x

Marton, F. \& Saljo, R. (1976b). On qualitative differences in learning: II. Outcome as a function of the learner's conception of the task, British Journal of Educational Psychology, 46, 115-127. https:/ / doi.org/10.1111/j.20448279.1976.tb02304.x

Newble, D. I., \& Clarke, R. M. (1986). The approaches to learning of students in a traditional and in an innovative problem-based medical school. Medical Education, 20(4), 267-273. https://doi.org/10.1111/j.13652923.1986.tb01365.x

Phan, H. P. (2011). Interrelations between self-efficacy and learning approaches: a developmental approach. Educational Psychology, 31(2), 225-246. https:/ / doi.org/10.1080/01443410.2010.545050

Postareff, L., Parpala, A., \& Lindblom-Ylänne, S. (2015). Factors contributing to changes in a deep approach to learning in different learning environments. Learning Environments Research, 1-19. https:// doi.org/10.1007/s10984-015-9186-1

Prince, M. J., \& Felder, R. M. (2006). Inductive teaching and learning methods: Definitions, comparisons, and research bases. Journal of Engineering Education, 95(2), 123-138. https://doi.org/10.1002/j.21689830.2006.tb00884.x

Prosser, M., \& Sze, D. (2014). Problem-based learning: student learning experiences and outcomes. Clinical Linguistics $\mathcal{E}$ Phonetics, 28(1-2), 131-142. https:/ / doi.org/10.3109/02699206.2013.820351

Prosser, M., \& Trigwell, K. (1999). Understanding learning and teaching: the experience in higher education. Buckingham: Society for Research into Higher Education.

Qatar University (QU). (2018). Qatar University Strategic Plan 2018-2022. Retrieved on March $12^{\text {th }, ~} 2018$ from http:/ / www.qu.edu.qa/static_file/qu/about/documents/Qatar\%20University\%20Strategy\%2020182022\%20Booklet\%20-\%20EN.pdf

Sabah, S., \& Du, X. (2018). University faculty's perceptions and practices of student centered learning in Qatar: Alignment or gap? Journal of Applied Research in Higher Education, 10(4), 514-533. https:/ / doi.org/10.1108/JARHE-11-2017-0144

Saravanamuthu, K., \& Yap, C. (2014). Pedagogy to empower Chinese learners to adapt to western learning circumstances: a longitudinal case-study. Cambridge Journal of Education, 44(3), 361-384. https:/ / doi.org/10.1080/0305764X.2014.914154

Scardamalia, M. (2002). Collective cognitive responsibility for the advancement of knowledge. In B. Smith (Ed.), Liberal education in a knowledge society (pp. 67-98). Chicago, IL: Open Court.

Scardamalia, M., \& Bereiter, C. (2006). Knowledge building: theory, pedagogy, and technology. In R. K. Sawyer (Ed.), The Cambridge handbook of the learning sciences (pp. 97-119). New York: Cambridge University Press.

Schmidt, H. G., Van der Molen, H. T., Te Winkel, W. W., \& Wijnen, W. H. (2009). Constructivist, problem-based learning does work: A meta-analysis of curricular comparisons involving a single medical school. Educational Psychologist, 44(4), 227-249. https://doi.org/10.1080/00461520903213592

Schultz, N., \& Christensen, H. P. (2004). Seven-step problem-based learning in an interaction design course. European Journal of Engineering Education, 29(4), 533-541. https:/ / doi.org/10.1080/03043790410001716248 
Scouller, K. (1998). The influence of assessment method on students' learning approaches: Multiple choice question examination versus assignment essay. Higher Education, 35(4), 453-472. https://doi.org/10.1023/A:1003196224280

Stahl, G. (2000). A model of collaborative knowledge-building. In B. Fishman \& S. O'Connor-Divelbiss (Eds.), Fourth international conference of the learning sciences (pp. 70-77). Mahwah, NJ: Erlbaum.

Strobel, J., \& Van Barneveld, A. (2009). When is PBL more effective? A meta-synthesis of meta-analyses comparing PBL to conventional classrooms. Interdisciplinary Journal of Problem-based Learning, 3(1), 4. https:/ / doi.org/10.7771/1541-5015.1046

Trigwell, K., \& Prosser, M. (1991). Relating approaches to study and quality of learning outcomes at the course level. British Journal of Educational Psychology, 61(3), 265-275. https://doi.org/10.1111/j.20448279.1991.tb00984.x

Zhao, K., \& Zheng, Y. (2014). Chinese Business English students' epistemological beliefs, self-regulated strategies, and collaboration in project-based learning. The Asia-Pacific Education Researcher, 23(2), 273-286. https:/ / doi.org/10.1007/s40299-013-0103-Z

Zhao, K., Zhang, J., \& Du, X. (2017). Chinese business students' changes in beliefs and strategy use in a constructively aligned PBL course. Teaching in Higher Education, 22(7), 785-804. https:/ / doi.org/10.1080/13562517.2017.1301908

\section{http://www.ejmste.com}

